\title{
The Improvement of Mathematical Problem Solving Ability and Self-Efficacy Students through Problem-Based Learning Model
}

\author{
${ }^{1}$ Cut Masturi, ${ }^{2}$ M. Ikhsan ${ }^{*}{ }^{3}$ Anizar Ahmad \\ ${ }^{1,2}$ Mathematics Education Program, Universitas Syiah Kuala, Banda Aceh, Indonesia \\ ${ }^{3}$ Early Childhood Education Program, Universitas Syiah Kuala, Banda Aceh, Indonesia
}

\begin{abstract}
This study aims to determine the improvement of problem solving ability of mathematics and selfefficacy of students through problem-based learning model. This research method used pre-test post- test control group design. The population in this study is all of Year 7 students of SMP Negeri 10 Banda Aceh. Two classes of samples were randomly selected, the experimental and the control classesThe research instrument consisted of a mathematical problem solving test and self-efficacy questionnaire. Data analysis was using t-test statistic. The result of the research showed 1) mathematical problem solving ability of students through problem-based learning model better than students who received conventional learning,

2) Self-efficacy of students who through problem-based learning model better than students who learn conventionally.
\end{abstract}

Keywords: Problem Based Learning, Self-Efficacy, Problem Solving Ability.

\section{Introduction}

Mathematics is one of the areas of study that students learn when in junior high. Knowledge of mathematics in junior high school will be the basis for studying mathematics in high school even tiered subsequent education. Mathematical concepts are structured hierarchically, logically, and systematically ranging from simple concepts to the most complex concepts. In mathematics there is a topic or a prerequisite concept as a basis for understanding the next topic or concept. Therefore the prerequisite concept must be completely mastered. Learning mathematics is not only required to master the concepts in mathematics, but students are also required to be able to apply the concept in solving everyday problems.

Problems in mathematics are defined as an issue that does not have routine procedures that can quickly be taken to determine the solution (Lesh \& Landau, 1983). Problems can be presented in the form of nonroutine questions, stories, phenomena or events, picture illustrations, or puzzles. The problem is then called a mathematical problem because it contains a mathematical concept. Bell (1983) states a situation is said to be a problem for a person if he or she is aware of the existence of the situation and acknowledges that the situation implies action and does not immediately find its solution. Hamzah (2003) states that a particular situation can be a problem for a particular person, but not necessarily a problem for others. In other words, a situation may be a problem for a person at any given time, but not necessarily a problem for him at a different time. A student will consider a question to be a problem if students have difficulty in finding solutions to problems or questions using the knowledge they have. Students will be able to solve a problem, if the student truly understands the principles that have been studied previously.

The low level of students' ability in solving mathematics problems is evidenced by a survey conducted by Trends in International Mathematics and Science Study (TIMSS), Indonesia is ranked 38th out of 42 countries with an average score of 386, while the average score of internationally 500. Conditions not much different from the results of the study conducted by PISA 2012 are more concerning, Indonesia is ranked 64th out of 65 countries participating or being on one level above Peru who was last with an average score of 375 , while the international average score of 500. In the TIMSS study it was revealed that Indonesian students were weak in solving non-routine problems related to justification or verification, solving problems that required mathematical reasoning, finding generalizations or conjectures, data or facts provided. 
The TIMSS survey results show that the majority of Indonesian students have not been able to develop their ideas and ideas in solving mathematical problems. Problem solving skills require analytical, reasoning, critical thinking skills, communicating effectively in problem solving. The low problem solving ability is caused by the lack of basic mathematical knowledge that should be owned by the child, and the unskilled children choose and apply the knowledge they have to solve the problem solving task (Napitupulu, 2011).

Relation of self-efficacy with problem-solving ability has a function as a tool to assess the success of students in solving problem-solving problems. According to Betz and Hacket (1981) self-efficacy mathematics further assesses each individual in judgment of their ability to solve certain mathematical problems and accomplish mathematical tasks. Self-efficacy can affect the success of the learning process and student achievement. Zimmerman (2000). In line with this, Liu, Cho and Schallert (2006) suggests that self-efficacy can improve problem-solving skills, so that students believe they can accomplish well-assigned tasks. Students who have high self-efficacy, are easier to participate in activities, have strong business, are not easily discouraged, and able to control their emotional reactions when faced with difficulties. While students who have low self-efficacy will doubt in their own ability, feel inadequate, easily give up, slow and easy to stress when faced with a difficult task (Bandura, 1997).

The results of preliminary observations and interviews with teachers in the field of mathematics studies at SMP Negeri 10 Banda Aceh about the process of students in solving mathematical problems, most students are easier in solving problems in the form of concepts and formulas. However, when faced with non-routine and application-shaped questions, students feel confused in converting into mathematical models. This happens because of the lack of basic mathematical knowledge that should be owned to solve difficult problems. Similarly, based on interviews with some students, most students lack confidence in opinion, answer, and ask questions in the learning process takes place. When faced with difficult problems, students feel inadequate and discouraged. In addition, when given time to do tuigas, students are always slow in mngerjakannya caused less confident with his own ability.

Based on the above problems, then one of the alternative methods of learning that allows to assist students in solving mathematical problems so as to develop problem-solving skills and self-efficacy of students in learning mathematics is a learning model problem based learning. Roh (2003) states that learning model problem based learning is a learning strategy that organizes or processes mathematical learning around problem solving and gives students the opportunity to think critically, propose their own creative ideas, and communicate to their friends mathematically. Learning model of problem based learning is a learning model that allows students to gain experience using the knowledge and skills they already have to apply to nonroutine problem solving.

The problem-based learning model is a learning-oriented model of problem-solving that is integrated in real life. Learning problem-based learning model expects students to form new knowledge or concepts of information obtained, so that students' thinking ability is really trained. Ferreira and Trudel (2012) explains that problem-based learning or problem-based learning has a positive impact on students' attitudes and can improve problem-solving skills as well as a sense of togetherness in the classroom. Learning model of problem based learning can also be interpreted as a learning model used to stimulate high-level thinking of students in situations oriented to real-world problems, including learning how to learn (Ibrahim \& Nur, 2005).

Stages of learning through problem-based learning approach or problem-based learning can be done through several steps. This study uses the stages of problem-based learning model according to Ibrahim and Nur (2005), ie 1) Student orientation to the problem, 2) organizing students to learn, 3) guiding the individual and group cultivation, 4) developing and presenting the work, (5) analyze and evaluate the problem-solving process.

Based on the background of the above problem, this research is conducted to investigate whether the improvement of problem solving ability of mathematics and self-efficacy of students taught with problembased learning model is better than the students taught conventional approach. 


\section{Methods}

This research is a quantitative research using pretest-posttest control group design. In this design there are two randomly selected groups, then given pretest to the two classes to know the student's early ability, then the learning is continued by applying the learning with problem based learning model (Class VII2) and applying the conventional approach to the control class (Class VII3), at the beginning and end of the learning are given pretest and postes to find out the improvement of problem solving ability of mathematics and self-efficacy of students from both sample classes. The population in this study are all students of class VII of SMP Negeri 10 Banda Aceh.

Instruments abilities problem solving skills used in this study followed indicator of problem-solving ability by NCTM established in a matter of describing the indicators (a) Identify the elements that are known, were asked, and the adequacy of the elements, (b) Formulate the problem fatherly construct mathematical models, (c) Implementing a problem-solving strategy, (d) Explaining and interpreting the results. The result of the pretest test of the mathematical problem solving abilities of students with the number of three items obtained a sufficient level of reliability that is $r=0.43$, with difficulty difficulty level there are two problems of medium and one difficult problem, and all the problems are valid and used. Questionnaire Self-efficacy consists of 25 questions. The self-efficacy indicators used in this study are based on three dimensions of self-efficacy according to Bandura (1997).

\section{Results and Discussion}

\section{Mathematical Problem Solving Analysis}

The results of the analysis of pretest data, obtained the average value and standard deviation in the experimental class is 15.79 and 5.77 while the average value and standard deviation on the control class is 15.67 and 5.51 of the maximum score of 48 . Average the preties of both classes are relatively similar, indicating that students' problem-solving abilities in both classes before learning are relatively similar. Based on test result of normality of pretest data in experiment class and control class of normal distributed data, then based on test of difference of average of pretest data in experiment class and control class there is no difference that both of them have the same ability.

Based on the results obtained from the two equality test the average value of Sig. (2-tailed) is $0.939>\alpha=$ 0.05 , meaning $H 0$ is accepted. This shows that there is no significant difference between the pretesting scores of students' mathematical problem solving abilities of experimental class and control class. Furthermore, the normality and homogeneity test for n-gain data mathematical problem solving. Obtained respectively for experimental class and Sig value control. 0.570 and 0.124 , the value of Sig.

$>\alpha=0.05$ so that the $\mathrm{N}$-gain value of mathematical problem solving ability of the experimental class students and the control class is normally distributed. For homogeneity test the N-Gain value of mathematical problem solving ability of experimental class and control class has value of Sig 0.928>0.05, meaning that experimental N-Gain data and control class come from homogeneous variance. Based on the result of normality test of $\mathrm{N}$-gain the ability of mathematical understanding of both

classes is normal homogenous distribution. Furthermore, the average difference test is done by using Uj-t with significance level $\alpha=0.05$. The test criterion is reject $H 0$ where Sig. $<\alpha$.

In summary, the average difference test of $\mathrm{N}$-gain ability of mathematical understanding is shown in the following table.

Table 1: Test differences mean gain-lumped ability mathematical problem

\begin{tabular}{|c|c|c|}
\hline \multicolumn{3}{|c|}{ t-test for Equality of Means } \\
\hline$T$ & $D f$ & Sig. (2-tailed) \\
\hline 6.072 & 46 & 0.000 \\
\hline
\end{tabular}

From Table 1. it is shown that the value of Sig. (2-tailed) is 0.000 . From the value of sig (2-tailed) is 0,000 the value of $\operatorname{sig}(1$-tailed $)=(\operatorname{sig}(2$-tailed $)) / 2=0,000 / 2=0,000$. Since the sig value $(1$-tailed $)$

$=0,000<\alpha=0.05$ then $\mathrm{H} 0$ is rejected, so H1 is accepted. Thus the first hypothesis that has been formulated in research that is "improvement of problem solving ability of student mathematics through model problem 
based learning better than student with conventional learning" accepted. The increase shows that in the activity of problem-based learning model can improve the ability of problem solving mathematically.

This is in accordance with the opinion of Ferreira and Trudel (2012) which states that learning model of problem based learning has an impact on students' attitudes and improve problem solving skills and sense of togetherness in the classroom. The results of this study are in accordance with several studies that found that learning model of problem based learning can improve students' mathematical problem solving abilities (Hidayah, 2013; Fitri, 2017; Yanti, 2016; Rokhmawati, Djatmika, \& Wardana, 2016; Sariningsih \& Purwasih, 2017).

\section{Student Self-Efficacy Analysis}

Student self-efficacy data is obtained from the questionnaire that has been converted into interval data by using Method of Successive Interval (MSI). Data were obtained through questionnaires given prior to treatment and after treatment in the experimental class and control class. The following is an analysis of the students' self-efficacy score scores in both classes.

Table 2: Description of student self-efficacy data

\begin{tabular}{|c|l|r|l|l|c|c|}
\hline \multicolumn{1}{|c|}{ Class } & $\mathbf{N}$ & Angket & $\begin{array}{l}\text { Max } \\
\text { Score }\end{array}$ & $\begin{array}{l}\text { Min } \\
\text { Score }\end{array}$ & $\bar{x}$ & SD \\
\hline Experiment & \multirow{2}{*}{24} & Before & 71.59 & 34.63 & 54.01 & 11.27 \\
\cline { 3 - 7 } & & After & 81.44 & 60.92 & 70.27 & 5.45 \\
\hline \multirow{2}{*}{ Control } & \multirow{2}{*}{24} & Before & 71.32 & 38.32 & 53.88 & 10.00 \\
\cline { 3 - 7 } & & After & 72.59 & 49.09 & 63.02 & 5.66 \\
\hline
\end{tabular}

Based on the Table 2. it is shown that the average self-efficacy of the students before the experimental and control class treatment is 54.01 and 53.88, respectively, from the ideal maximum score of 100 . This shows that the students' self-efficacy in both classes before learning is relatively the same. In the spreading of student self-efficacy between the experimental class and the control class is relatively the same, because the standard deviation of the two classes is not much different that is 11.27 and 10.00 .

The mean of questionnaire score after treatment was obtained experimental class and control class were 70,27 and 63,02 respectively so that the experiment class average was higher than the control class average for student self-efficacy. This shows that there is an increase in self-efficacy score of students after learning through problem based learning model. From the normality test and homogenity of pretest self-efficacy it is found that the value of Sig. for the experimental and control classes respectively of 0.301 and $0.141>0.05$ so that $\mathrm{H0}$ is accepted, the two students' self-efficacy data from both classes are normally distributed and Sig.0,786> 0.05 which means that the self-efficacy

data of the experimental class and control class derived from a homogeneous variance. Then t-test is done to find the equality of the two classes and the result of Sig. (2-tailed) is $0.967>0.05$. So there is no difference between the two classes of self-efficacy.

The next test of normality and homogeneity of the N-gain of the two groups. Obtained successive experimental class and Sig control. 0.109 and $0.120>0.05$ and for homogeneity $0.192>0.05$, it means that the N-Gain data self-efficacy of the experimental class students and the control class is normal and comes from the homogeneous variance. The result of analysis of mean difference of $\mathrm{N}$ - gain self-efficacy of experiment class and control class based on result of data processing got Sig value. (2-tailed) is 0.000. From the value of sig $(2$-tailed $)=0,000$, the value of sig $(1$-tailed $)=(\operatorname{sig}(2$-tailed $)) / 2=0,000 / 2=0,000$. Since the sig value $(1$-tailed) $=0,000<0.05$ then is $H 0$ rejected and $H 1$ is accepted.

Thus it can be concluded that the second hypothesis which states "the increase in self-efficacy of students taught through model problem-based learning better than the self-efficacy of students taught through conventional learning" is accepted. This suggests that involving students actively in learning activities as well as being aware of their own abilities can improve student self-efficacy. The results of this study are in accordance with several previous studies which concluded that the model of learning- based learning can 
improve student self-efficacy (Aprilia \& Jalmo \& Marpaung, 2015; Listiani, 2016; Yanti, 2016; Wiratmaja, 2014; Rokhmawati et al., 2016; Sariningsih \& Purwasih, 2017).

\section{Conclusion}

Based on the result of this research, it can be concluded that (1) the improvement of students' mathematical problem solving skills taught through problem based learrning model is better than students taught through conventional learning, (2) Increasing self-efficacy of students taught through problem based learning model is better than students taught through conventional learning.

Some of the suggestions in this research are (1) This research is only limited to comparative material, it is expected in other researchers to develop learning with problem based learning model on other mathematical ability and other appropriate materials, (2) On the implementation of learning model problem-based learning may have obstacles at the beginning of the learning so that the need for anticipation of teachers and students need to be trained to answer the problems of mathematics, (3) research on self-efficacy students have not been maximally done by researchers and have a limited time that is only six times meeting. It is therefore necessary to research about student self-efficacy over a longer period of time to see the processes and factors that can improve student self-efficacy.

\section{Reference}

[1.] Aprilia, Y., Jalmo, T., \& Marpaung, R. R. T. (2015). Pengaruh Problem Based Learning Dalam Meningkatkan Self-Efficacy Dan Hasil Belajar. Jurnal Bioterdidik, 3(10), 43-58.

[2.] Bandura. A. (1997). Self-efficcay. The Exercise of Control. New York: W. H. Freeman and Company.

[3.] Bell, A.W. (1983). Diagnosing Students Misconceptions. The Australian Mathematics Teacher. Melbourne.

[4.] Betz, N. E., \& Hackett, G. (1981). The Relationship of Career-Related Self-Efficacy Expectations to Perceived Career options in College Women and Men. Journal of Counseling Psychology, 28(4), 399-410.

[5.] Ferreira, M.M., \& Trudel, A.R. (2012). The Impact of problem Based learning on Student Attitude Toword Scieence, Problem Solving Skill and Sense of Community in The Classroom. Journal of Classroom Interction, 47(1 ), 23-30.

[6.] Fitri, R.Y. (2017). The Effect of Problem Based Learning Model (PBL) and Adversity Quotient on Problem Solving Ability. Journal of Educational Research, 5(2), 179-183.

[7.] Hamzah. (2003). Meningkatkan Kemampuan Memecahkan Masalah Matematika Siswa Sekolah Lanjutan Tingkat Pertama Negeri di Bandung melalui Pendekatan Problem Posing. Dissertation, Bandung: PPS UPI, unpublished.

[8.] Hidayah, M. (2013). Penerapan Problem Based Learning dalam Pembelajaran Matematika Untuk Peningkatan Kemampuan Pemecahan Masalah Pada Siswa Kelas VIII Semester II SMPN 1 Teras. Thesis, Universitas Muhammadiyah Surakarta, unpublished.

[9.] Ibrahim, \& Nur (2005). Pengajaran Berdasarkan Masalah. Surabaya: Universitas Press.

[10.] Lesh, \& Landau.(1983). Problem Solving In. T.R. post (ed). Teaching Mathematics in Grades K-8; Research-based Methods 2-nd Edition. Boston, M.A: Aly and Bacon.

[11.] Liu, M., Cho, Y., \& Schallert, D. L. (2006). Middle School Students' Self-Efficacy, Attitudes, and Achievement in a Computer-Enhanced Problem-Based Learning Environment. Journal of Interactive Learning Research, 17(3), 225-242.

[12.] Listiani, W (2016). The Enchancement of Mathematical Critical Thinking Skills and Self- Efficacy at Senior High School Students Though Learning Bsed problem Contextual Model. Journal of Mathematics Education, 1(1), 56-62.

[13.] Napitupulu, E. (2011). Pengaruh Pembelajaran Berbasis Masalah, atas Kemampuan Penalaran Matematis, Kemampuan Pemecahan Masalah Matematis, dan Sikap Siswa terhadap Matematika Siswa menengah Atas. Dissertation, Bandung: PPS UPI, unpublished.

[14.] Roh, K. H. (2003). Problem-Based Learning in Mathematics. ERIC Digest. ERIC Identifier: EDOSE-03-07. [Online]. Tersedia: http://www.ericdigest.org. 
[15.] Rokhmawati, J.D., Djatmika, E.T., \& Wardana, L. (2016). Implementation of Problem Based Learning Model to Improve Students' problem Solving Skill and Self-Efficacy. Journal of Research \& Method in Education, 6(3), 51-55.

[16.] Sariningsih, R., \& Purwasih, R (2017). Pembelajaran Problem Based Learning untuk Meningkatkan Kemampuan Pemecahan Masalah Matematis dan Self-Efficacy Mahasiswa Calon Guru. Jurnal Nasional Pendidikan Matematika, 1(1), 163-177.

[17.] Wiratmaja, C. (2014). Pengaruh Model Pembelajaran Berbasis Masalah Terhadap Self-Efficacy dan Emotional Intelligence Siswa SMA. e-Journal Program Pascasarjana Universitas Pendidikan Ganesha Program Studi IPA,4(1), 1-11.

[18.] Yanti, A. A. (2016). Penerapan Model Pembelajaran Problem Based Learning untuk Meningkatkan Kemampuan Pemecahan Masalah dan Komunikasi Matematis serta Self-Efficacy Siswa SMP. Thesis, Bandung: UNPAS, unpublished.

[19.] Zimmerman, B. J. (2000). Self-efficacy: An Essential Motive to Learn. Contemporary Educational psychology, 25(1), 82-91. 